\title{
PELATIHAN KETERAMPILAN TANGAN MENGGUNAKAN MEDIA KAIN FLANEL 'PENGENALAN JENIS BINATANG' SEBAGAI PROSES KREATIF SISWA PAUD ANGGREK ROSALINA 011
}

\author{
Adisti Ananda Yusuff, Putri Anggraeni Widyastuti \\ Program Studi Desain Interior, Fakultas Desain Industri Kreatif, Universitas Esa Unggul \\ Jalan Arjuna Utara no.9 Jakarta Barat 11510 \\ Adisti.ananda@esaunggul.ac.id
}

\begin{abstract}
Early childhood education or known by the abbreviation paud is an effort that aims to give guidance for children aged from birth to the age of 6 years. One of a breed offrequently used in the program of them are fisik-motorik development programs and the arts, which includes a bereksplorasi to grow and atmosphere, expression, and appreciation in the context of play. Hence the course of development is given through the stimulus of education by educator in the learning through the atmosphere play, moreover the pandemic conditions at the moment and skills training craft based flannel cloth to be applied to the students of early childhood. In the pandemic and still the PSBB by the government, so paud orchid rosalina 011 apply system sfh ( school from home) by granting homework learning of the assistance that can be done by .. parentsThis led to the process oflearning and creative process delayed obtained by students getting limited .To respond to these problems and the devotion to the community provide a solution in the form of skills training module handicrafts which is packed into a package of skill and supplied with tutorials in a masing-masing pembuatanya to do at home. Method the survey conducted from the place paud and interview by head paud school rosalina difficulty orchid to know what was going on in learning distance is so far.After then in preparation phase of the package disesuikan module that have provided the of the curriculum.To produce a package of module in training cloth flanel into a picture frames the the introduction of animals.An output that picture frames produced will be a can decked in accordance with creativity them to get creative process to having the value of aesthetics and art
\end{abstract}

Keywords : early childhood education programs, children creativity, distance learning

\begin{abstract}
Abstrak
Pendidikan Anak Usia Dini atau yang dikenal dengan singkatan PAUD merupakan upaya pembinaan yang bertujuan untuk memberikan pembinaan kepada anak usia sejak lahir hingga usia 6 tahun. Salah satu jenis kurikulum yang digunakan pada program PAUD diantaranya adalah program pengembangan fisik-motorik dan seni, yang mencakup perwujudan suasana untuk berkembang dan bereksplorasi, ekspresi, dan apresiasi dalam konteks bermain. Oleh karena itu program pengembangan ini diberikan melalui rangsangan Pendidikan yang dilakukan pendidik dalam kegiatan belajar melalui suasana bermain, terlebih untuk kondisi pandemic pada saat ini maka pelatihan keterampilan kerajinan berbahan dasar kain flannel akan diterapkan pada siswa siswi PAUD. Ditengah masa pandemic dan masih diberlakukannya PSBB oleh pemerintah, maka PAUD Anggrek Rosalina 011 menerapkan system SFH (School From Home) dengan cara memberikan pekerjaan rumah berupa buku pembelajaran yang bisa dikerjakan dengan dampingan orang tua.. Hal ini menyebabkan proses pencapaian pembelajaran menjadi terhambat sehingga proses kreativitas yang didapat oleh para siswa menjadi terbatas. Untuk menanggapi permasalahan tersebut maka tim pengabdian kepada masyarakat memberikan sebuah solusi berupa modul pelatihan keterampilan kerajinan tangan yang sudah dikemas menjadi sebuah paket keterampilan dan disertakan dengan tutorial cara pembuatan ya untuk dikerjakan di rumah masing-masing Metode pelaksanaan yang dilakukan mulai dari survey lokasi tempat PAUD dan juga wawancara langsung kepala sekolah PAUD Anggrek Rosalina guna mengetahui kesulitan apa yang terjadi dalam proses pembelajaran jarak jauh ini. Setelah itu kemudian tahapan pelaksanaan berupa persiapan paket modul yang sudah disesuikan dengan tema dari kurikulum yang disediakan. Hingga menghasilkan sebuah modul berupa paket pelatihan pemanfaatan kain flannel menjadi sebuah bingkai foto dengan tema pengenalan binatang. Output yang dihasilkan berupa sebuah bingkai foto yang bisa dihias sesuai dengan kreativitas mereka agar mendapatkan proses kreatif hingga memiliki nilai estetika dan seni.
\end{abstract}

Kata kunci : pendidikan anak usia dini, kreativitas anak, sekolah jarak jauh

\section{Pendahuluan}

Adanya pandemic Covid-19 membuat seluruh institute Pendidikan baik itu negeri dan 
swasta merubah system pembelajarannya. Keadaan memaksa untuk melakukan pembelajaran secara jarak jauh dan menghindari kontak dan tatap muka secara langsung guna menghindari penyebaran virus Covid-19. Hal ini berdampak dan dirasakan juga oleh PAUD Anggrek Rosalina 011 Kota Tangerang. PAUD ANggrek Rosalina didirikan di Kota Tangerang oeh Walikota Tangerang pada saat itu yaitu H.Wahidin Halim dengan nomor izin pendirian 421.10/Kep.28.PAUD/BPPMPT/2013. Sekolah PAUD Anggrek Rosalina dipimpin oleh kepala sekolah bernama Dra.Anik Warda. Lokasi sekolah yang berada ditengah perumahan nasional 2 Kota Tangerang menjadi salah satu PAUD yang diandalkan warga sekitar karena berada ditengahtengah perumahan sehingga menjadi strategis, lokasi ini dijadikan lokasi kegiatan pengabdian masyarakat oleh tim Fakultas Desain dan Industri Kreatif Universitas Esa Unggul. PAUD Anggrek Rosalina 011 memiliki bangunan yang multifungsi karena difungsikan juga sebagai tempat untuk melaksanakan kegiatan posyandu dan poswindu bagi masyarakat setempat. Hingga saat ini PAUD Anggrek Rosalina 011 telah banyak membantu berbagai macam kegiatan dan aktif dalam mengikuti perlombaan yang diselenggarakan oleh kecamatan Cibodas Kota Tangerang.

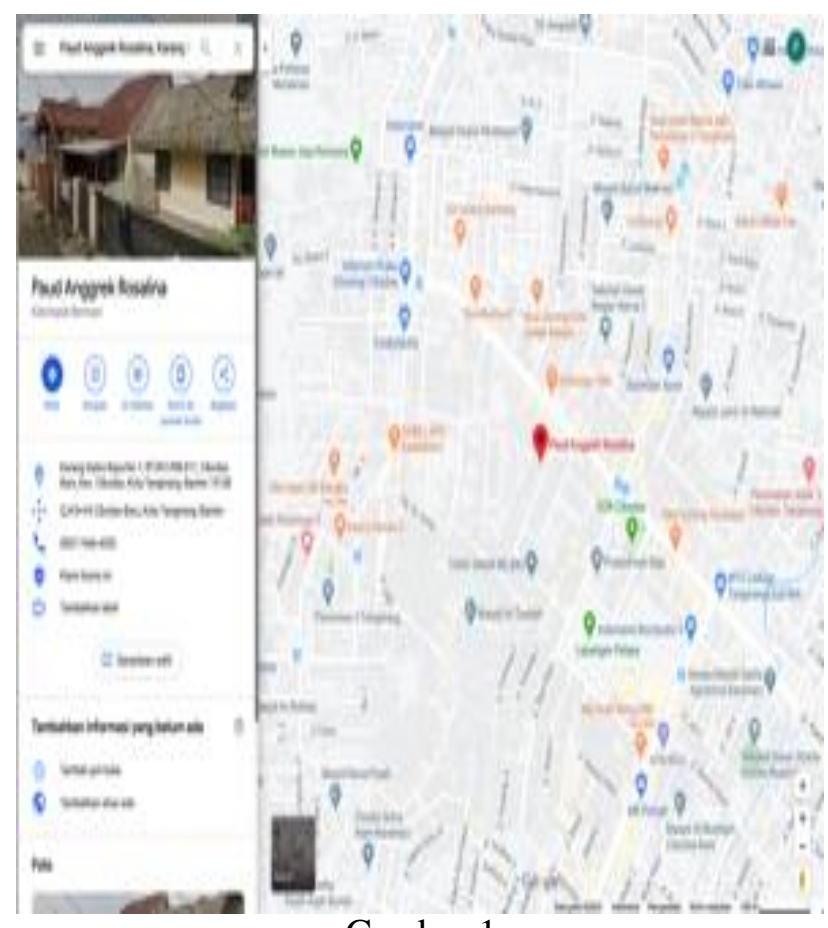

Gambar 1

Lokasi PAUD Rosalina 011

Sumber: https://www.google.co.id/maps/place diunduh tanggal 25 April 2020 jam 06.55 WIB

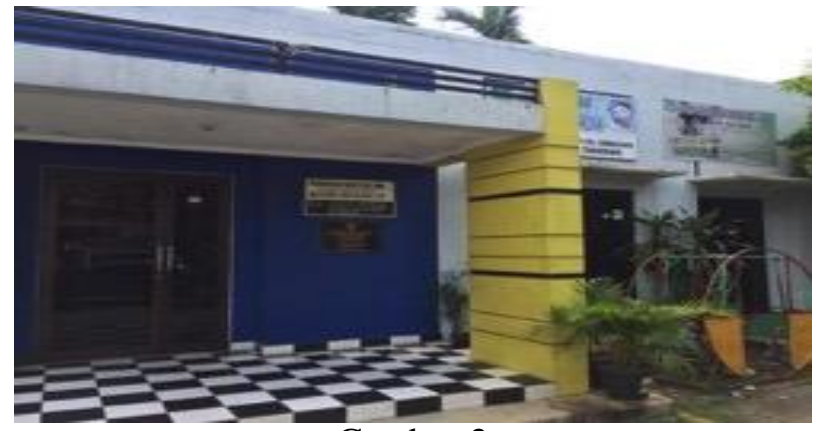

Gambar 2

Tampak Depan PAUD Rosalina 011

Sumber: pribadi 2020

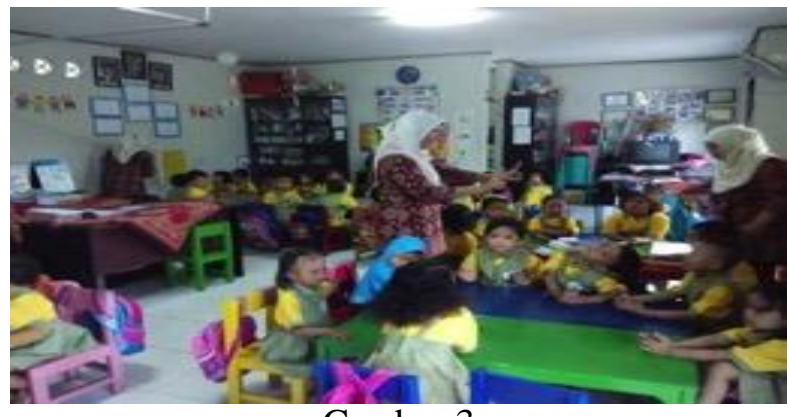

Gambar 3

Suasana Pembelajaran PAUD Rosalina 011 sebelum masa covid-19

Sumber: PAUD Anggrek Roslina 011- 2020

Sebelum teradinya pandemic Covid-19 sekarang ini, PAUD ANggrek Rosalina selalu melakukan kegiatan pembelajaran tatap muka sesuai dengan peraturan Menteri Pendidikan dan Kebudayaan Republik Indonesia Nomor 146 Tahun 2014 mengenai kurikulumm 2013 Pendidikan Anak Usian Dini pada Lampiran 3 yang membahas mengenai Pedoman Pengembangan Kurikulum Tingkat Satuan Pendidikan Anak Usia Dini. Pendekatan pembelajaran yang tepat dan sesuai dengan anak usia dini akan menentukan keberhasilan anak dalam mencapai perkembangan yang optimal sesuai dengan karakteristik, mita dan potensinya. Dengan berkembangnya pola ini maka masin-masing anak memiliki kemampuan dan kesiapan mental untuk mencapai pembelajaran pada jenjang selanjutnya. Kesiapan ini ditentukan dari tercapainya kompetensi sikad, keterampilan dan juga pengetahuan yang sesuai dengan perkembngan zaman. Semua ini sesuai dengan lingkup pembelajaran pada PAUD yang meliputi seluruh Kompetensi Dasar yang memadukan seluruh unsur engembangan yaitu diantaranya nilai agama dan juga moral, fisik motoric, kognitif, Bahasa, social - emosional, dan juga seni. Sehingga pelaksanaan pembelajaran yang digunakan oleh PAUD Anggrek Rosalina 011 ini dilakukan kegiatan pendekatan pembelajaran yang digunakan pada kurikulum 2013, yaitu pendekatan tematik terpadu. Dalam model pembelajaran tematik 
terpadu ini kegiatan kegiatan yang dilakukan untuk satu tema, sub tema, atau sub sub tema dirancang untuk mecapai secara Bersama sama kompetensi sikap, pengetahuan, dan keterampilan dengan mencakup Sebagian dan seluruh aspek perkembangan.

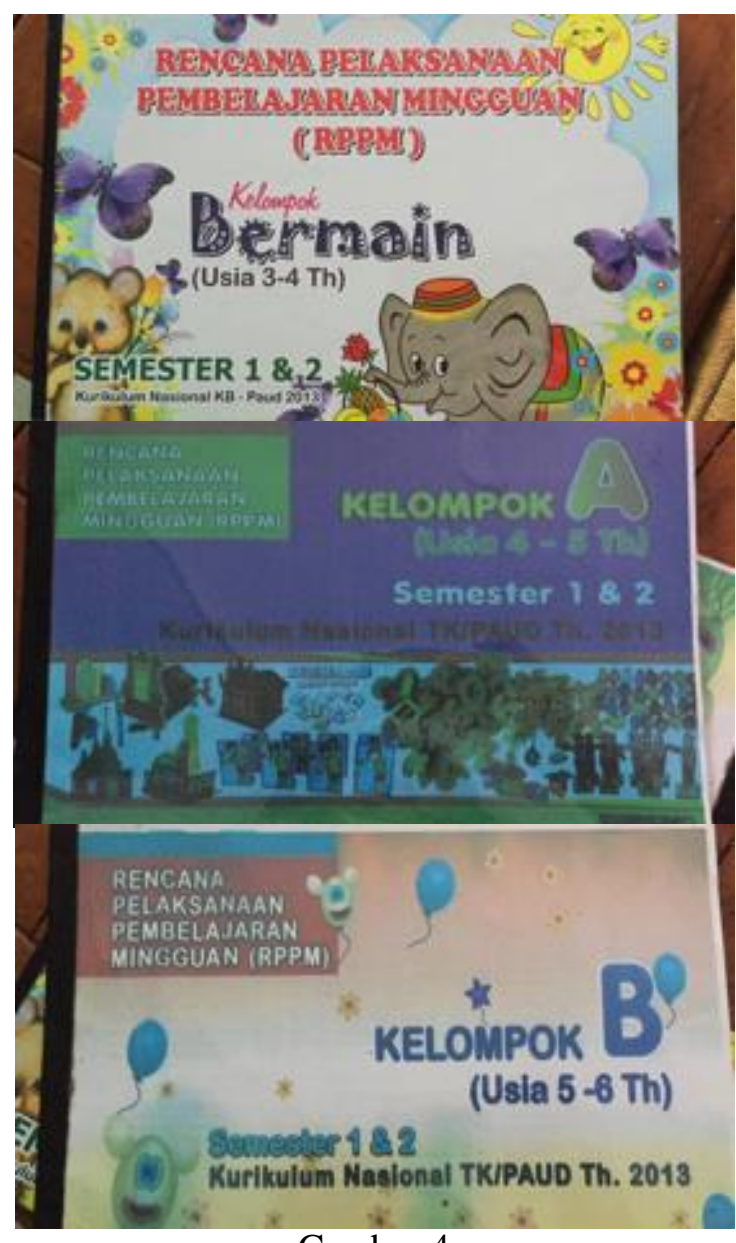

Gambar 4

RPPM usia 3-6 tahun Yang Digunakan PAUD

Anggrek Rsalina 011

Sumber: PAUD Anggrek Roslina 011, 2020

Pembelajaran yang dilakukan melalui pembelajaran secara tatap muka atau langsung dan pembelajaran secara daring atau tidak langsung yang terjadi scara terintegrasi dan tidak terpisah. Pembelajaran secara lagsung merupakan proses pembelajaran melalui iteraksi dan tatap muka antara gur dan juga murid dirancang dalam Rencana Pelaksanaan Pembelajaran Mingguan (RPPM) dan Rencana Pelaksanaan Pembelajaran Harian (RPPH). Pembelajaran secara tatap muka atau langsung sesuai dengan pengembangan pengetahuan dan keterampilan yang terkandung dalam Kompetensi Inti-3 (pengetahuan) dan Kompetensi Inti-4 (keterampilan). Sedangkan pembelajaran secara daring atau tidak langsung dirancang secara khusus agar mencapai kompetensi pengetahuan dan keterampilan, akan terjadi dampak dlam pengembangan nilai dan sikap yang terkandung dalam Kompetensi Inti-1 (sikap spiritual dan Kompetensi Inti-2 (sikap sosial). Oleh karena itulah tim pengabdian masyarakat Fakultas Desain dan Industri Kreatif Universitas Esa Unggul melakukan pelatihan keterampilan kerajinan tangan dengan mteri yang menyesuaikan pada isi dari RPPM dan RPPH pada kurikulum tahun 2013 yang dimiliki oleh PAUD ANggrek Rosalina 011, salah satu tema yang tercantum adalah pengenalan jenis binatang dengan media kain flannel, dikarenakan dibutuhkanna pembelajaran yang dapat memacu kreativitas siswa makan pengenalan jenis binatang dimasukan kedalam pembuatan karya bingkai foto. Para peserta yang diikutsertakan merupakan seluruh siswa dari PAUD Anggrek Rosalina 011 yang terbagi dari kelompok bermain, kelompok A dan Kelompok B dengan rentang usia antar 3-6 tahun. Dibuat dengan tingkat kesulitan yang berbeda sesuai dengan usia dari siswa tersebut.

Disamping itu ada sebuah jurnal karya Primadi Tabrani mengenai Limas Citra Manusia yang berjudul "Pendidikan Seni, HubnganNya Dengan Ambang Sadar Imajinasi dan Kreativitas Serta Manfaat Untuk Proses Belajar yang Bermutu" menjelaskan bahwa Proses belajar $=$ Proses Kreasi. Temuan ini didapatkan oleh Primadi Tabrani bahwa Limas Citra Manusia yang disingkat dengan Limas, antara lain merupakan perpaduan Citra Rasional dan Citra Kreatif manusia, dapat digunakan secara praktis didalam dunia Pendidikan.

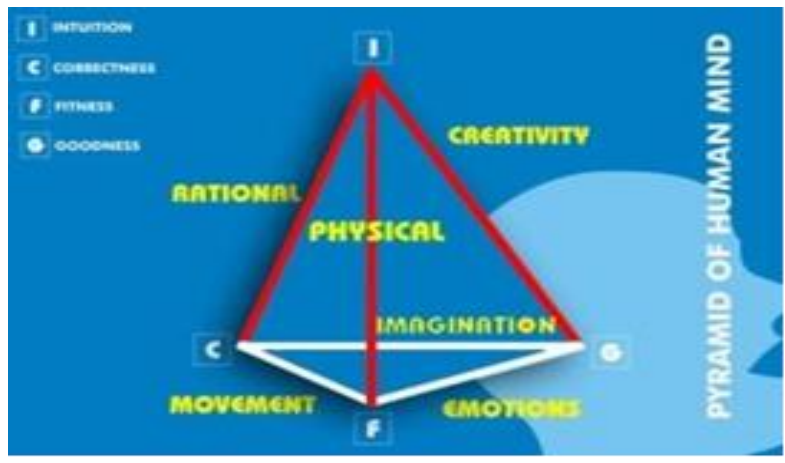

Gambar 5.

Limas Citra Manusia (Limas)

Sumber: Primasi Tabrani, 2015

Beliau menjelaskan bahwa Limas ini sudah banyak digunakan dalam pembelajaran kreatif atau yang biasa disebut dengan creative learning di berbagai kegiatan di Pendidikan Anak Usia Dini (PAUD), Kelompok Bermain, dan juga Taman Kanak Kanak (TK). Dari pendapat inilah maka dilakukan kegiatan pengabdian masyarakat oleh tim FDIK di PAUD Anggrek Rosalina 011, dikarenakan FDIK merupakan fakultas yang bergerak pada bidang desain, seni, dan jga dunia kreativitas sehingga 
berhubungan erat dengan proses kreatif. Selain itu kegiatan ini juga bertujuan untuk meningkatkan proses kreativitas pada siswa PAUD Anggrek Rosalina 011 melalui proses keterampilan yang juga membantu para guru PAUD dalam hal pemberian materi materi baru selama masa pandemi saat ini.

Dengan diberlakukannya PSBB

(Pembatasan Sosial Berskala Besar) oleh pemerintah pusat Negara Indeonesia yang sudah ditetapkan di 10 wilayah Indonesia dikarenakan semakin meluasnya tingkat penyebaran Virus Covid-19, membuat pembelajaran dan tenaga pendidik khususnya di PAUD Anggrek Rosalina 011 harus menyesuaikan sistem pembelajaran yang sudah dibuat menjadi berubah. Apalagi lokasi yang berada di Kota Tangerang yang masih menjadi zona merah penebaan kasus virus Covid-19 mmbuat kondisi pembelajaran dipaksa beradaptasi dengan menetapkan system SFH (School From Home) dengan memberikan pekerjaan rumah berupa buku paket yang harus dikerjakan dengan pendmpingan orang tua masing masing siswa.

Pembelajaran jarak jauh tau yang disebut juga denga WFH masih mengacu pada RPPM dan RPPH yang terdapat pada kurikulum tahun 2013, dimasa semua siswa PAUD harus memiliki capaian kompetensi yang sudah tertulis pada kurikulum. Ditambah dengan RPPM dan RPPH pada kurikulum 20013 menggunakan pendekatan pembelajaran yang memiliki tema dan sub ema melalui strategi pembelajaran dengan konteks bermain. Ini dilakukan guna merangsang perkembangan dari kreativitas para siswa PAUD Angrek Rosalina 011 dengan cara memberikan stimulus berupa media pembelajaran dan keterampilan menggunakan material kain flannel dengan tema pengenalan jenis binatang yang mengacu pada RPPM dan RPPH agar pembelajaran mereka dapat tetap berjalan sesuai dengan arahan dengan baik. Namun adanya keterbatasan yang terjadi yaitu tidak adanya tatap muka antara siswa dan guru membuat pengontrolan pembelajaran dirasa mengalami kendala. Proses pencapaian pun menjadi terhambat selain keterbatasan alat dan bahan yang digunakan oleh pihak sekolah pun terbatas sehingga proses kretaif yang didapat oleh para siswa PAUD Anggrek Rosalina 011 mengalami kendala.

\section{Solusi dan Target Luaran}

Guna menangani permasalahan yang ada, maka kami im pengabdian masyarakat FDIK Universitas Esa Unggul memberikan solusi penanganan permasalahan yang ada di PAUD Anggrek Rosalina 011 ini, salah satnya dengan cara melakukan kegiatan melalui keterampilan kerajinan tangan yang sudah dikemas menjadi sebuah paket keterampilan yang berisikan alat, bahan, dan tata cara pembuatan nya. Isi paket keterampilan ini telah melalui proses persetujuan dari guru dan kepala sekolah melalui proses pemeriksaan terlebih dahulu. Kemudian paket keterampilan ini dibagikan kepada orang tua murid siswa PAUD Anggrek Rosalina untuk dibawa pulang dan dikerjakan pada rumah masing masing. Kepala sekolah dari PAUD Anggrek Rosalina menyambut dengan sangat terbuka tujuan baik dari tim pengabdia masyarakat FDIK Universitas Esa Unggul. Sehingga diharapkan kegiatan ini akan berjalan lancer kedepannya.

Paket keterampilan ini menjadi bagian dari kegiatan pengbdian kepada masyarakat menggunakan media kertas sebagai proses kreatif siswa PAUD Anggrek Rosalina 011ini. Pelatihan keterampilan ini tidak lepas dari RPPM dan RPPH yang menjadi panduan dalam pelaksaan kegiatan ini. Sehingga tim pengabdian masyarakat mendiskusikan dengan para tenaga pendidik yang ada pada PAUD Anggrek Rosalina 011 kemudian disarankan menggunakan RPPM dan RPPH yang mereka gunakan agar meskipun dalam masa SFH di pandemic ini siswa PAUD Anggrek Rosalina 011 tetap dapat mencapai kompetensi pencapaian yang telah disususn pada kurikulim 2013 utnuk PAUD. Dengan kondisi itu, maka tim pengabdian masyarakat FDIK Universitas Esa Unggul memutuskan untuk membuat stimulus menggunakan material berbahan dasar kain flannel dengan tema pengenalan jenis binatang.

Sebagai bagian dari kegiatan ini, maka tim harus membuat luaras, Adapun luaran dari kegiatan pengabdian masyarakat ini adalah Latihan proses keterampilan kerajinan tangan sebagai proses kreatif yang akan diperkenalkan kepada siswa PAUD ANggrek Rosalina 011. Proses kretif yang sama dengan proses belajar ini merupaka tujuan capaian dari luaran kegiatan pengabdian masyarakat FDIK Universitas Esa Unggl. Mahasiwa un turut serta untuk belajar dan beriterakis langsung maupun tidak lagsung dengan para orang tua dan pada tenaga pendididk. Diharapkan pengenalan material kain flannel ini dapat meningkatkan kemampuan kerajinan tangan dan meningkatkan proses kretaif dengan menambah pengetahuan mengenai matrial baru dan pengenalah jenis binatang bagi siswa PAUD ANggrek Rosalina 011. Luaran lain dari kegiatan ini merupakan jurnal dan HKI dalam bentuk laporan akhir yang akan dilaorkan pada universita Esa Unggul.

\section{Metode Pelaksanaan}

Pelaksanaan pengabdian masyarakat dilaksanakan di PAUD Anggrek Rosalina 011 Jl.Karang Kates Raya RW.11 Perumahan Nasional 2 Kecamatan Cibodas Kota Tangerang. Kegiatan ini 
berlangsung mulai tanggal 1 April 2020 hingga 4 Agustus 2020. Berikut ini merupakan tabel jadwal kegiatan pengabdian masyarakat yang dibuat oleh tim Fakuktas Desain dan Industri Kreatif Universitas Esa Unggul.

Tabel 1

Jadwal Kegiatan P2M

\begin{tabular}{|c|c|c|}
\hline No & Tanggal & Kegiatan \\
\hline 1 & $\begin{array}{l}1 \quad \text { April } \\
2020\end{array}$ & Survey ke lokasi mitra \\
\hline 2 & $\begin{array}{l}20 \text { April } \\
2020\end{array}$ & $\begin{array}{l}\text { Survey peralatan untuk } \\
\text { pelatihan ke mitra }\end{array}$ \\
\hline 3 & $\begin{array}{l}27 \text { April } \\
2020\end{array}$ & $\begin{array}{l}\text { Serah terima surat ijin ke } \\
\text { mitra dari FDIK }\end{array}$ \\
\hline 4 & $\begin{array}{l}30 \text { April } \\
2020\end{array}$ & Penyerahan Proposal \\
\hline 5 & $\begin{array}{l}2 \\
2020\end{array}$ & $\begin{array}{l}\text { Pembelian peralatan untuk } \\
\text { pelatihan }\end{array}$ \\
\hline & & \begin{tabular}{lrr} 
Pelatihan & \multicolumn{2}{c}{ Keterampilan } \\
Kerajinan & \multicolumn{2}{c}{ Tangan } \\
Menggunakan & Media & Kain \\
Flanel "Pengenalan & Jenis
\end{tabular} \\
\hline 6 & 11 Mei & Binatang" kepada Siswa \\
\hline U & 2020 & $\begin{array}{l}\text { PAUD Anggrek Rosanila 011, } \\
\text { dengan cara menyerahkan } \\
\text { paket pembelajaran kepada } \\
\text { para orang tua siswa PAUD } \\
\text { Rosalina } 011\end{array}$ \\
\hline & Juni & 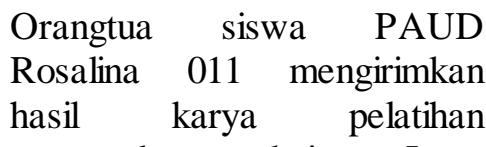 \\
\hline 7 & 2020 & $\begin{array}{l}\text { pengenalan pakaian Jawa } \\
\text { Barat ini menggunakan daring } \\
\text { dengan whatapps sebagai } \\
\text { bukti pelatihan }\end{array}$ \\
\hline 7 & $\begin{array}{l}10 \text { Juni - } \\
14 \\
\text { Agustus } \\
2019\end{array}$ & $\begin{array}{l}\text { Pembuatan laporan akhir } \\
\text { pengabdian } \\
\text { masyarakat oleh tim }\end{array}$ \\
\hline
\end{tabular}

Adapun tahapan tahapan dan langkah pelaksanaan kegiatan pengabdian masyarakat yang merupakan soulusi yang ditawarkan untuk mengatasi permasalahan PAUD Anggrek Rosalina 011 adalah :

1. Dibutuhkan adanya survey lokasi selama beberapa hari untuk memahami lokasi pengabdian pada masyarakat.

2. Dari survey lokasi dibuat dokumentasi baik foto, atau video berdasarkan pendekatan fenomenologi.

3. Dalam pendekatan fenomenologi melibatkan segala panca indera dan melakukan pendeskripsian.

4. Dilakukan perjanjian surat menyurat administrasi antara ketua pelaksana kegiatan pengabdian kepada masyarakat dengan pihak mitra terkait, yakni Ketua PAUD Anggrek Rosalina 011 yaitu ibu Dra.Anik Warda

5. Proses surat menyurat untuk perjanjian kegiatan pengabdian kepada masyarakat inipun ditentukan jadwal pelaksanaannya agar tidak merepotkan ihak mitra itu sendiri. Mengingat mitra dalam hal ini adalah PAUD Anggrek Rosalina 011 telah memiliki kalender akademik sekaligus RPPM dan RPPH yang harus dijalani selama masa kegiatan pembelajaran sehingga mau tidak mau ketua pelaksana pengabdian kepada masyarakat dan tim.

6. Ketua dan tim pelaksana kegiatan pengabdian kepada masyarakat menyiapkan materi dan peralatan yang digunakan utnuk pelatihan keterampilan kerajinan tangan menggunakan media kain flanel dengan tema pengenalan jenis binatang.

7. Pada pelaksanaanya ketua dan tim dibantu oleh 5 mahasiswa Fakultas Desain dan Industri Kreatif Universitas Esa Unggul melakukan kegiatan keterampilan kerajinan tangan menggunakan media kain flanel dengan tema pengenalan jenis binatang sebagai proses kreatif siswa PAUD Anggrek Rosalina 011.

8. Hasil pelaksanaan pelatihan didokumentasi dengan baik sebagai bukti pelaksana kegiatan pengabdian kepada masyarakat.

Peran dan pastisipasi PAUD Anggrek Rosalina 011 dalam pelaksanaannya diantaranya yaitu adalah menjadi narasumber dalam pengumpulan data yng akan digunakan pada Pelatihan Keterampilan Kerajinan Tangan Menggunkan Media Kain Flanel "Pengenalan Jenis Binatang" Sebagai Proses Kreatif Siswa PAUD Anggrek Rosalina 011. Adapula pendekatan yang dilakukan dengan mitra selain dengan menggunakan fenomenologi selain itu juga menggunakan metode eksplorasi material. Pendekatan eksplorasi material dilakukan dengan cara melatih anak untuk merasakan secara inderawi material maupun peralatan yang digunakan selama proses kegiatan berlagsung. Tahapan dari proses pngerjaan dijelaskan secara rinci dari tahap per tahap sesuai dengan kebutuhan usiannya yaitu untuk kelompok bermain. Kelompok A dan kelompok B. Ketua tim dan pelaksana kegiatan pengabdian kepada masyarakat untuk sisawa PAUD Anggrek Rosalina 011 didampingi oleh para pengajar dari taip kelompok yang ada pada PAUND Anggrek Rosalina 011 dan telah disepakati oleh ketua pelaksana pengabdian kepada masyarakat dan juga kepala 
sekolah PAUD Anggrek Rosalina 011 melalui media komunikasi digital yang dilakukan sebelum acara pengabdian kepada masyarakat berlangsung. Setelah selesai kegiatan kemudian diadakan sebuah evaluasi pelaksanaan program pengabdian kepada masyarakat baik itu secara internal (tim pengabdiam masyarakat) dan juga secara ekspernal (dengan mitra yang terkait) supaya kedepannya tetap ada keberlanjutan program yang dapat dilakukan kembali dan juga menjadi bahan pembelajaran untuk pengabdian masyarakat di kemudian hari.

Tahap survey awal yang dilakukan berupa penyampaian maksud dan tujuan pelaksanaan pengbdian mesyarakat yang akan dilaksanakan, kemudian setelah mendapatkan izin dari kepala sekolah PAUD Anggrek Roalina 011 untuk melaksanakan kegiatan pengabdian masyarakat kemudian masuk kedalam tahap diskusi mengenai alur dan jadwal kegiatan yang akan dilaksanakan. Mengingat kegiatan ini dilaksanakan di tengah pandemik covid-19 maka kegiatan dan diskusi lebih banyak dilakukan dengan menggunkan grup diskusi dan juga media teleconference aplikasi zoom. Selain itu mahasiswa yang ikutserta pun tidak semua hadir didalam kegiatan pengabdian kepada masyarakat dikarenakan jarak lokasi tempat tinggal dan keterbatasan transportasi pribadi yang menjadikan ketua pelaksana melakukan arahan agar hanya perwakilan mahasiswa saja yang hadir dalam acara kegiatan tersebut. Slebihnya mahasiswa lain yyang tidak hadir ikut andil didalam bagian pembuatan paket pembelajaran dan juga pembuatan video dan tata cara pembuatan paket keterampilan yang dibagkan kepada siswa siswa PAUD Anggrek Rosalina 011.

Berikut merupakan dokumentasi kegiatan yang telah dilakukan olh tim pengabdian masyarakat Fakultas Desain dan Industri Kreatif Universitas Esa Unggul, mulai dari survey awal, tahap pelaksanaan, dan juga tahap diskusi pelaksanaan dengan mahasiswa.

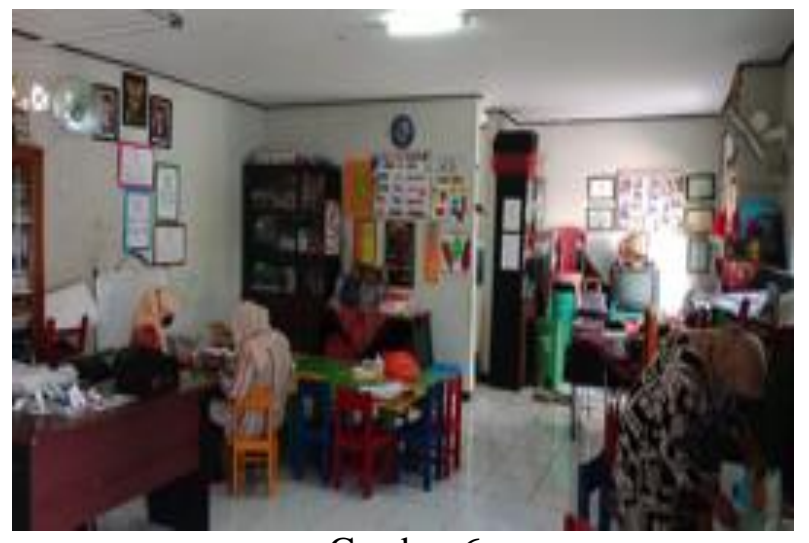

Gambar 6

Survey Awal PAUD Anggrek Rosalina 011

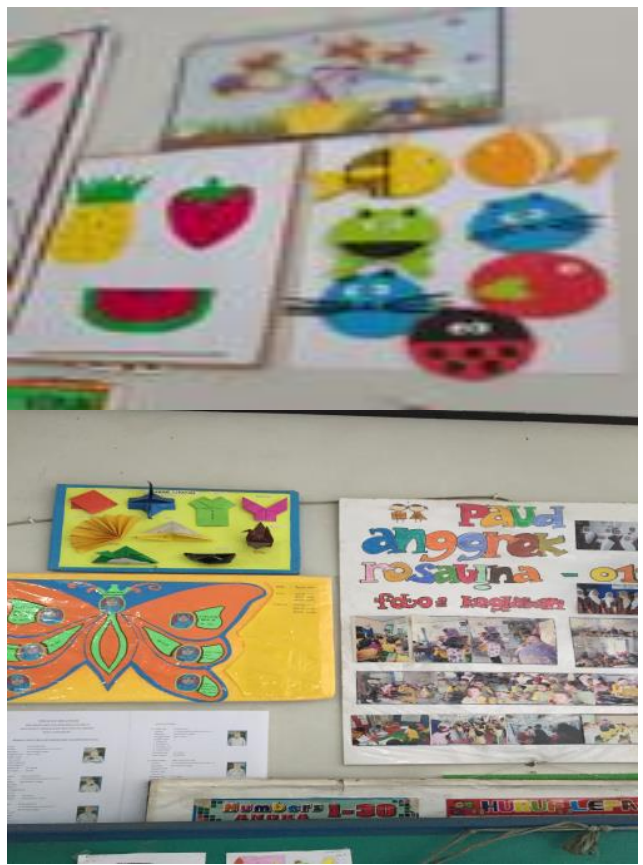

Gambar 7

Survey Awal PAUD Anggrek Rosalina 011-karya siswa

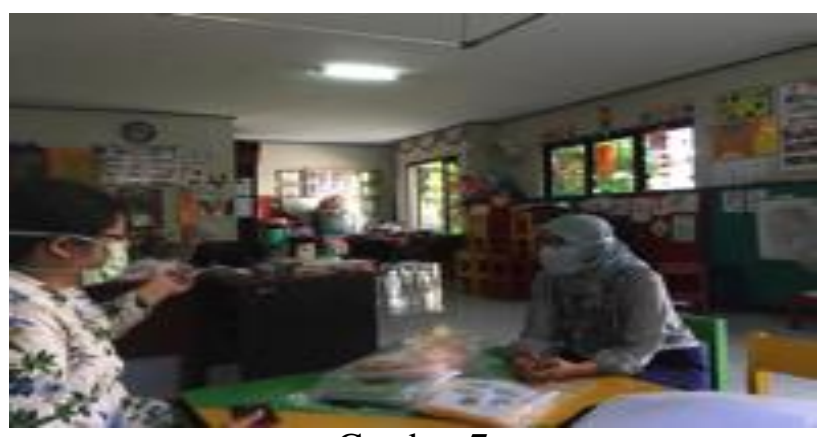

Gambar 7

Pertemuan dengan perwakilan PAUD Angrrek Rosalina 011

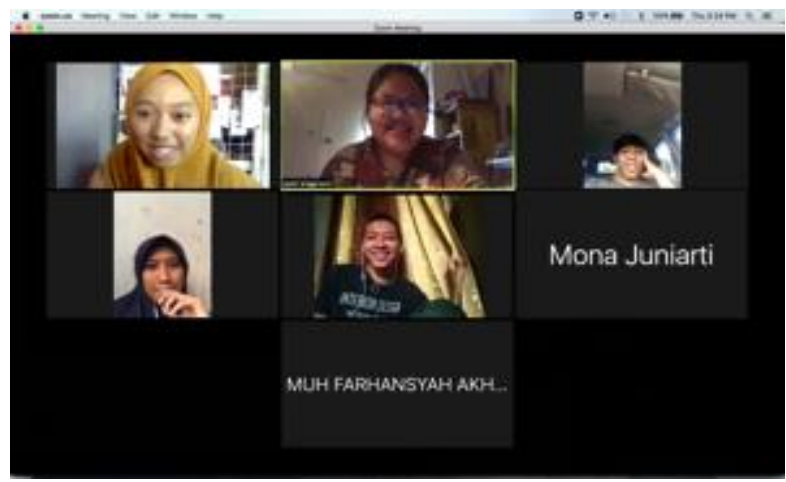

Gambar 8

Group diskusi tim pengabdian kepada masyarakat dilakukan melalu media zoom

\section{Hasil dan Pembahsan}

Hal yang pertama dilakukan sebelum dilaksanakannya kegiatan pelatihan keterampilan kerajinan tangan menggunakan media kain flannel sebagai proses kreatif siswa PAUD Angrrek 
Rosalina 011 yang merupakan kegiatan pengabdian masyarakat yang dilakukan oleh tim dari Fakultas Desain dan Industri Kreatif Universitas Esa Unggul yaitu emilihan Teknik yang tepat sasaran yang dapat digunakan sesuai dengan media kain flannel, mengingat target kegiatan pengabdian kepada masyarakat ini merupakan siswa siswi PAUD yang memiliki usia sekita 1 tahun -6 tahun serta keadaan yang mengharuskan kita untuk membatasi kegiatan diluar ruangan dan berkumpul maka tim memutuskan untuk membuat keterampilan berupa Menyusun dan menempel bingkai foto dengan jenis binatang yang telah disediakan dalam paket keterampilan sesuai dengan keinginan dan kreativitas masing - masing siswa.

Adapun Langkah selanjutnya adalah pemilihan jenis material kain flannel yang digunakan harus menggunakan kain flannel yang memiliki tekstur yang sedikit kaku agar dapat berdiri tegak Ketika bingkai foto akan dipajang. Setalah itu baru pembuatan hiasan jenis binatang dan juga bentuk-bentuk lainnya untuk hiasan yang akan ditempel oleh para siswa dibuat dengan beberapa jenis bentuk dan percobaan. Bentuk-bentuk yang dipilih sesuai dengan tema yang sudah ditentuka dari pihak sekolah yaitu tema binatang dan juga beberapa jenis bentuk dan tumbuhan.

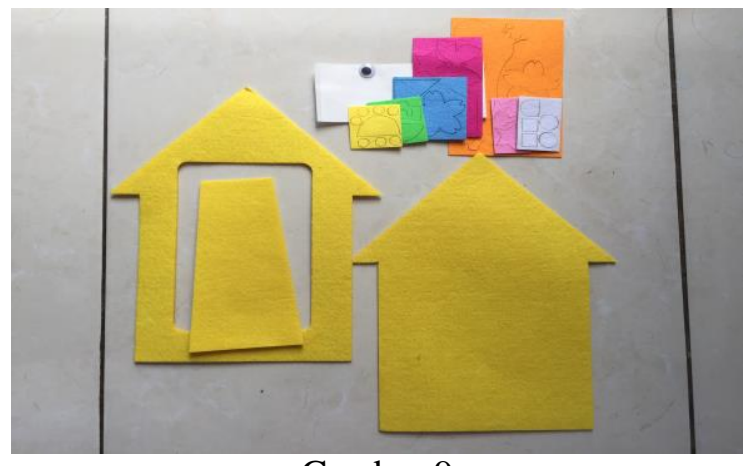

Gambar 9

Pembuatan Bentuk Bingkain Foto dan Hiasannya Untuk Paket Keterampilan Siswa PAUD

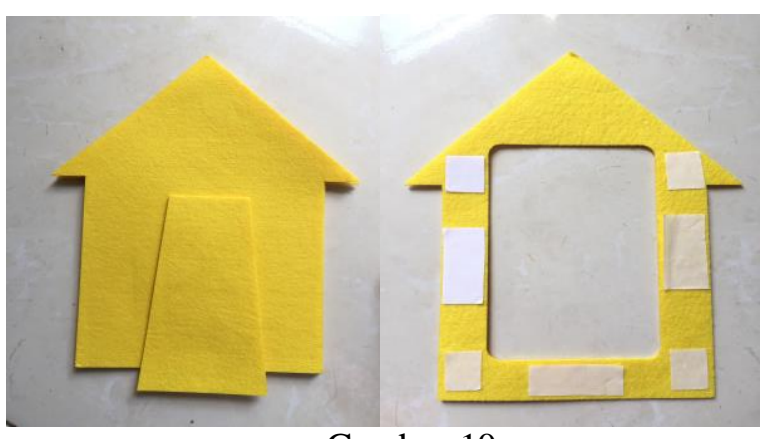

Gambar 10

Pembuatan Teknik Penempelan Bingkai Foto Untuk Paket Ketermpilan Siswa PAUD

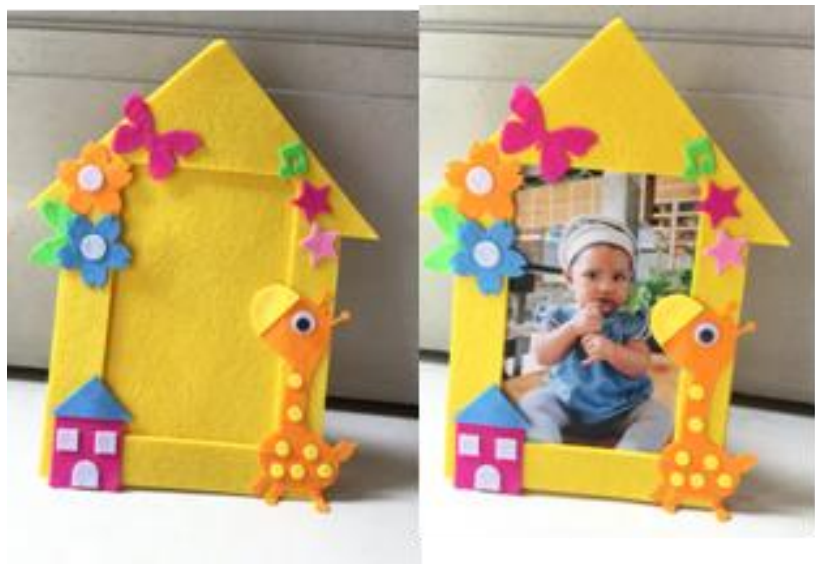

Gambar 11.

Contoh Hasil Paket Keterampilan yang Dibagikan Kepasa Siswa PAUD

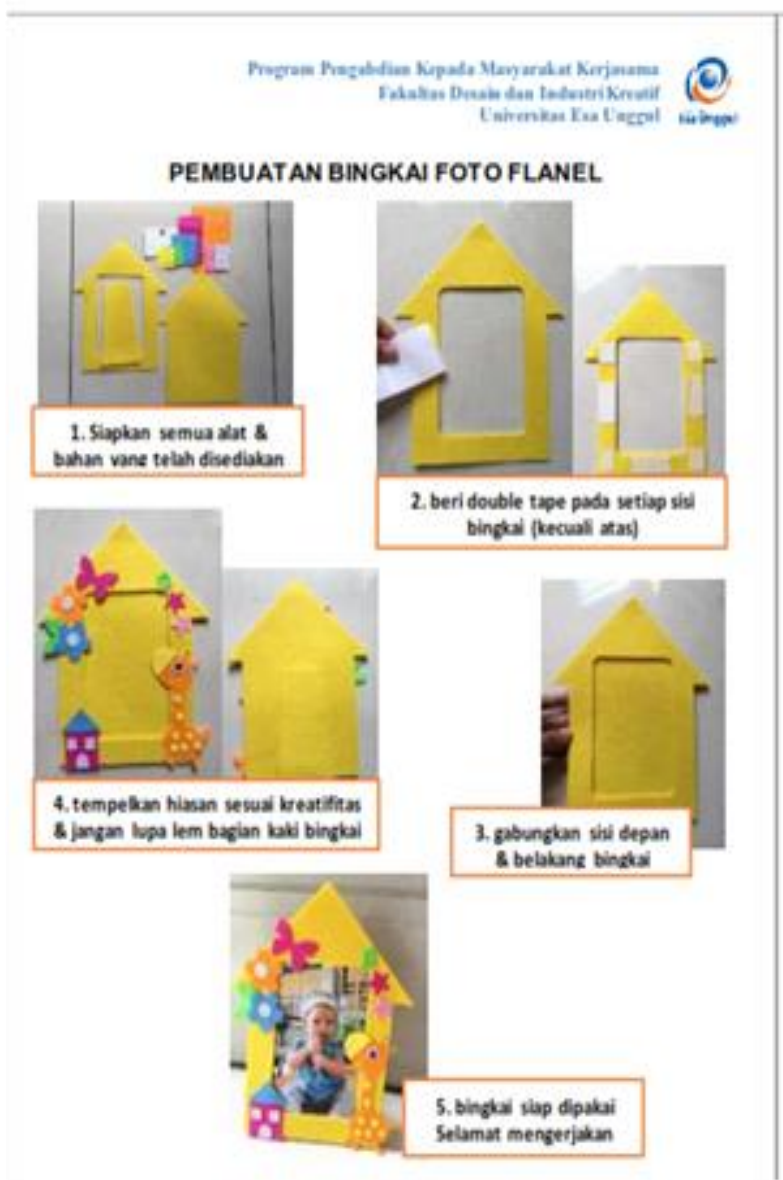

Gambar 12.

Tutorial Pengerjaan Paket Keterampilan yang Dibagikan Kepasa Siswa PAUD

Pelaksanaan kegiatan pengabdian kepada masyarakat dilaksanakan dimulai dengan tim pengabdian kepada masyarakat endatangi PAUD Anggrek Rosalina 011 tetap dengan protocol Kesehatan yang diberlakukan yaitu dengan penggunaan masker dan jaga jarak sesame. Selain itu pada hari yang sama PAUD ANggrek Rosalina juga mengundang orang tua mahasiswa untuk 
melakukan pembagian pakter keterampilan yang telah disiaplkan. Agar tidak terjadinya penumpukan jumlah orang yang dating maka dibuat jadwal pembagian paket keterampilan , tiap pertemuan dilakukan hanya maksimal 5 orang tua siswa dan juga hanya berlangsung maksial 20 menit untuk dilakukan pembagian dan penjelasan dari guru yang bersangkutan.

Setlah paket keterampilan diterima oleh para orang tua siswa PAUD Anggrek Rosalina 011 kemudian para siswa mengerjakan pada rumah masing masing dengan dampingan dari para orang tua . dan bagi krya yang sudah selesai dikerjakan mereka unggah didalam grup media social sekolah yang telah dibuat oleh pihak sekolah PAUD Anggrek Rosalina 011 yaitu whatssapp grup ebagai sebuah hasil luaran kompetensi siswa yang telah sesuai dalam pelaksanaan kegiatan pembelajaran sesuai dengan RPPM dan RPPH yang berlaku.

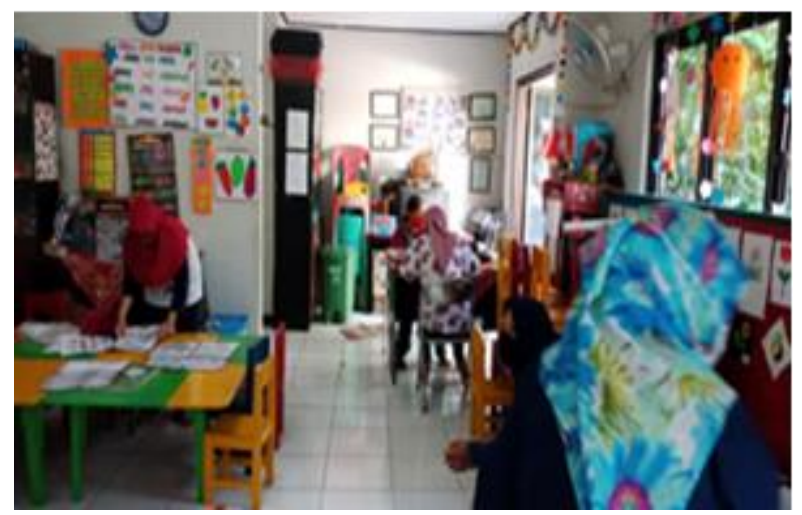

Gambar 13.

Suasana PAUD Anggrek Roalina pada Hari Pelaksanaan

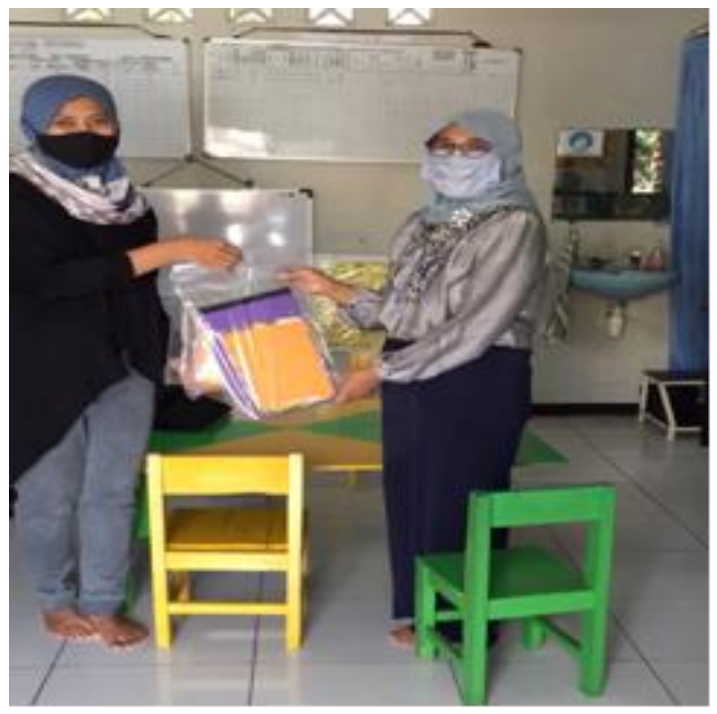

Gambar 14.

Penyerahan Paket Keterampilan Secara Simbolik Kepada Kepala Sekolah PAUD Anggrek Rosalina 011

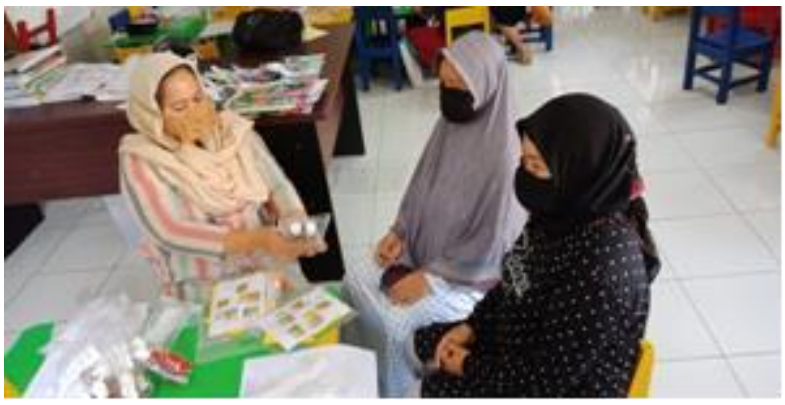

Gambar 15.

Penyerahan Paket Keterampilan Kepada Para Orang Tua SIswa PAUD ANggrek Rosalina 011

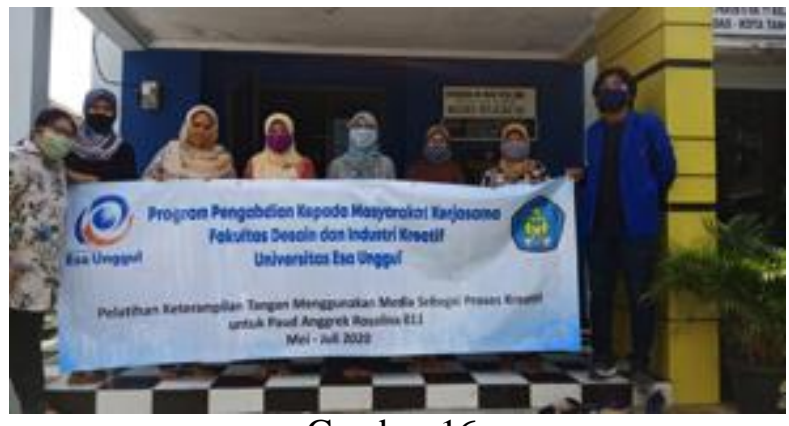

Gambar 16.

Foto Bersama Tim Pengabdian Masyarakat dan Guru PAUD Anggrek Rosalina 011

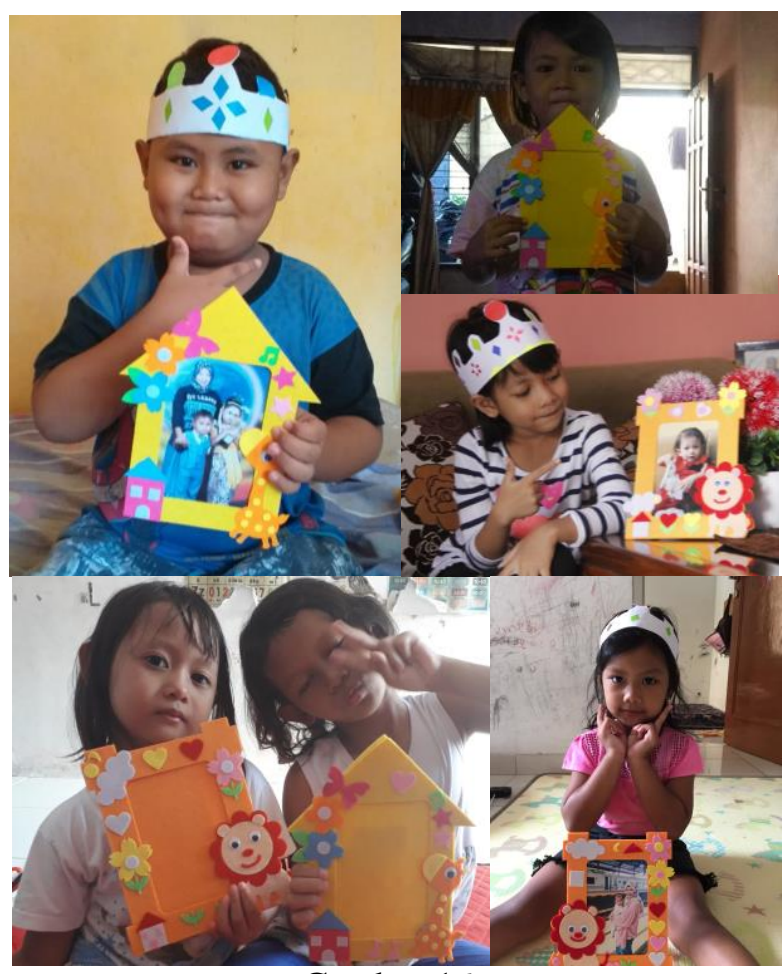

Gambar 16

Foto Bersama Tim Pengabdian Masyarakat dan Guru PAUD Anggrek Rosalina 011

\section{Kesimpulan}

Dari hasil kegiatan pengabdian kepada masyarakat yang telah dilaksanakan oleh tim Fakultas Desain dan Industri Kreatuf Universita 
sEsa Unggul yang berlokasi di PAUD Angrrek Rosalina 011 maka dapat disimpulkan bahwa kegiatan pegabdian masyarakat yang terlaksana di tengah pandemic Covid-19 ini merupakan jawaban dan juga bantuan yang sangat bermanfaat bagi para guru dan siswa PAUD Anggrek Rosalina 011 dimasa pelaksanaan pembelajaran jarak jauh pada saat ini. Kegiatan pembelajaran bisa tetap teraksana sesuai dengan RPPM dan RPPH yang berlaku dan telah disusun sebelumnya sehingga dengan adanya bantuan dari tim pengabdian masyarakat para guru yang semula kesulitan karena andemi ini berlangsung secara mendadak mendapatkan angin segar dari kegiatan yang dilaksakan ini. para guru dan tim pun berusaha semaksimal mungkin agar kegiatan pembelajaran dan pelaksanaan kegiatan ini berjalan sesuai dengan yang telah disusun sebelumnya.

Paket keterampilan yang dibuat dan dikemas bertujuan untuk memudahkan distribusi penyerahan kepada masing-masing orang tua siswa PAUD Anggrek Rosalina dan sudah dilengkapi dengan tutorial pembuatannya sehingga menjadikan output dari kegiatan ini sesuai dengan yang diharapkan. Kemudian seluruh siswa yang aktif pun mengunggah hasil dari paket keteranpilan melalui media whattsapp grup yang telah dibuat oleh pihak sekolah PAUD Angrrek Rosalina 011 sebagai bentuk kompetensi hasil pembeljaran yang diharapkan.

Harapan kedepannya agar kegiatan ini bisa dilangsukan secara rutin selama 1 semester pembelajaran PAUD Anggrek Rosalina 011 selama masih dilaksanakannya pembelajaran jarak jauh seingga para siswa dapat selalu berkreativitas dan berekspresi meskipun mereka mengerjakan di rumah masing masing.

\section{Daftar Pustaka}

Adian, Donny Gahral. (2010). Pengantar Fenomenologi, Depok: Penerbit Koekoesan.

Endraswara, Suwardi. (2006). Metodologi Penelitian Kebudayaan, Cetakan ke-2. Yogyakarta: Gadjah Mada University Press.

Jones, Sue Jenkyn. (2005). Fashion Design Second Edition London: Laurence King Publishing.

KEMENDIKBUD. (2015). Peraturan Menteri Pendidikan Kebudayaan Republik Indonesia Nomor 146 Tahun 2014 Tentang Kurikulum 2013 Pendidikan Anak Usia Dini, Indonesia : Kementerian Pendididikan Kebudayaan Republik Indonesia.
Nugraha, Adhi, dkk. (2018). Craft dan Desain Indonesia - Sudut Pandang Akademik dan Pelaku, Bandung: Aliansi Desainer Produk Industri Indonesia.

Tabrani, Primadi. (1998). Proses Kreasi, Apresiai, Belajar, Bandung: Penerbit Institut Teknologi Bandung.

Tabrani, Primadi. (2015). Pendidikan Seni, Hubungannya Dengan Ambang Sadar, Imajinasi Dan Kreativitas Serta Manfaatnya Untuk Proses Belajar Yang Bermutu. Vol. 7, No. 1, Jurnal Komunikasi Visual dan Multimedia, Bandung: Institut Teknologi Bandung. 